Journal of Agricultural Sciences
(Tarim Bilimleri Dergisi)

\title{
Investigation of Flight Activity and Damage Status of European Grapevine Moth Lobesia botrana (Denis \& Schiffermuller) (Lepidoptera: Tortricidae)
}

\author{
Ayşe ÖZDEM $^{\mathrm{a} *}$ (D), Arzu AYDAR ${ }^{\mathrm{a}}\left(\mathbb{D}\right.$, Yasemin SABAHOĞLU ${ }^{\mathrm{a}}$ (D)

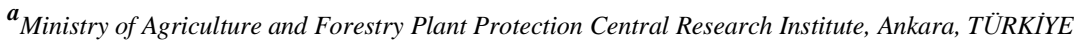 \\ ARTICLE INFO \\ Research Article \\ Corresponding Author: Ayşe ÖZDEM, E-mail: aozdem1@ @otmail.com \\ Received: 15 September 2020 / Revised: 01 December 2021 / Accepted: 05 December 2021 / Online: 15 October 2022 \\ Cite this article \\ ÖZDEM A, AYDAR A, SABAHOĞLU Y (2022). Investigation of flight activity and damage status of European grapevine moth Lobesia botrana (Denis \& Schiffermuller) (Lepidoptera: \\ Tortricidae). Journal of Agricultural Sciences (Tarim Bilimleri Dergisi), 28(4):704-710. DOI: 10.15832/ankutbd.795425
}

\section{ABSTRACT}

The present study was carried out between 2013 and 2014 in vineyards in Ankara province on the Kalecik karası grape variety. The aim was to determine the biological characteristics of Lobesia botrana (Denis \& Schiffermuller, 1775) (Lepidoptera: Tortricidae) such as adult flight activity, the duration of its presence in nature and the number of generations per year. These characteristics are essential for the control, as well as for the evaluation of the damage status. During this study, the first adults of $L$. botrana were caught in April and the first peak of the pest was seen in the last week of April in both years. The second peak of the pest occurred in the second-third week of June and it produced two generations per year. It was also determined that the flight of adults ended in September. European grapevine moth adults were found to be active for about six months. Although there were European grapevine moths in the vineyard during the control and count at vegetation and harvest period, there were no eggs and larvae or damage on grapes during harvest of both years. The results of this study clearly demonstrate that it is not necessary to use chemicals to control of $L$. botrana in the vineyards of Kalecik karasi.

Keywords: Lobesia botrana, population, Integrated pest management, Damage, Kalecik karas1

\section{Introduction}

Turkey ranks among the top countries in terms of vineyards and grape production. The grape production area comprises of 4054307 decares, and 2050000 tons are produced for table grapes, 1599000 tons for dried grapes and 451000 tons for wine production, making up the total production of 3600000 tons (TUIK 2019). Ankara province provides 1.2\% of Turkey's wine production. Despite the decline in vineyard areas across Turkey, viticulture in Kalecik district of Ankara province has shown a rapid development with public and private sector investments in the field of viticulture. Kalecik karası is a standard quality grape variety, suitable for red wine, produced in the Central Anatolia Region (Karataş et al. 2010).

While many diseases and pests require chemical control in vineyards, Lobesia botrana is the main pest in vineyards (Davydov 1976; Altındişli \& Kısmalı 1996; Anonymous 2008). The larva of the European grapevine moth causes damage in the vineyard by eating buds, flowers, unripe grape and ripe ones. It causes abscission during budding and flowering period as well as rotting during the unripe and ripe grape harvest (Anonymous 2008). It affects the product in terms of both quality and quantity. Wine produced from grapes damaged by L. botrana has low quality. L. botrana infestation negatively affects taste, smell and alcohol content of wine (Altındişli 2014). According to studies done in different regions, it has been observed that the damage of vineyards due to L. botrana range between 45-92\% in the Aegean region (Önçağ 1975), and between 34-52\% in Şanlıurfa in the Southeastern Anatolia region (Mamay \& Çakır 2014). According to the studies performed in different countries, the European grapevine moth, which is a polyvoltine species, generates 2 to 4 generations annually depending on geographical areas and climatic conditions (Martin-Vertedor et al. 2010; Caffarra et al. 2012; Pavan et al. 2013; Gilioli et al. 2016). L. botrana generally has three generations in our country; however, the species produces two generations in some vineyards in the Central Anatolia Region where our study has been conducted (Anonymous 2008). Since L. botrana is the main pest in vineyards, many studies have been carried out from past to present on population change, biology and control of the pest in different regions of our country.

The present study was conducted in vineyards in Kalecik district of Ankara province between 2013 and 2014 and the adult flight activity, the main control against European grapevine moth and important criteria such as climate data and the phenology of vineyard were evaluated together and the damage status was investigated. This study is the first in-depth study on the European grapevine moth in the Central Anatolian Region and aims to obtain basic data on the management strategy of pest control. 


\section{Material and Methods}

Trials were carried out in a vineyard of $15 \mathrm{da}$, in which Kalecik karası grape variety was cultivated, in the district of Kalecik of Ankara province. This area was infected with the European grapevine moth Lobesia botrana Den. \& Schiff. (Lepidoptera: Tortricidae). The trial vineyard was established according to the two-tier cordon training system with a trunk of $70 \mathrm{~cm}$ and an offshoot height of 110-120 cm whereas the distance between rows was $3 \mathrm{~m}$ and the distance above rows was $1.5 \mathrm{~m}$. Pherocon type (Trece ${ }^{\circledR}$ incorporated Pherocon ${ }^{\circledR}$ CAP) sex pheromone traps (E-7, Z-9-dodecadienyl acetate) used to monitor the flight activity of European grapevine moth and a METOS computerized climate device used to obtain climate.

Starting from January 1, when the sum of the maximum temperatures reached $1000{ }^{\circ} \mathrm{C}, 2$ traps/da of sex pheromone traps were hung in the trial vineyard to identify the adult flight activity of L. botrana (Anonymous 2011). These traps were hung to the south of vine stocks, at the level of clusters and a height of approximately $50 \mathrm{~cm}$ from the ground in the prevailing wind direction. The pheromone traps were checked twice a week until the first adult was obtained and once a week after the first adult was obtained, and the number of adults was counted and recorded. The pheromone capsules were changed every 4-5 weeks or when the sticky tray of these traps got dirty.

After the first adults were caught, the presence of first generation eggs in the flower buds were checked if the temperature was above $15{ }^{\circ} \mathrm{C}$ for at least two consecutive nights and continued in the following days. Control of the first generation larvae was carried out when the total effective temperature reached 120 days degrees, starting from January 1. A loupe was used (40X) for the control of larvae. When it reached 520 degrees/days (d/d), a control was performed whether larvae of European grapevine moth were produced in the second generation. At least 150 clusters were checked at each count. During the harvest at least 150 clusters randomly selected from the inner and outer part of grapevines at four directions were checked for any larvae damage. Phenological periods of the grapevine were recorded in both years (Anonymous 2011). Climate data in the two years of the study was obtained using a METOS computerized climate device, $50 \mathrm{~m}$ away from the vineyard area.

\section{Results and Discussion}

Starting from January 1, when the maximum total of temperatures reached $1000{ }^{\circ} \mathrm{C}, 2$ traps/ha of sex pheromone traps were hung to identify the adult flight activity of L. botrana on April 4, 2013, and on April 2, 2014. The first adults in pheromone traps were caught on April 22, 2013, and on April 17, 2014 The population trend is given in Figures 1 and 2.

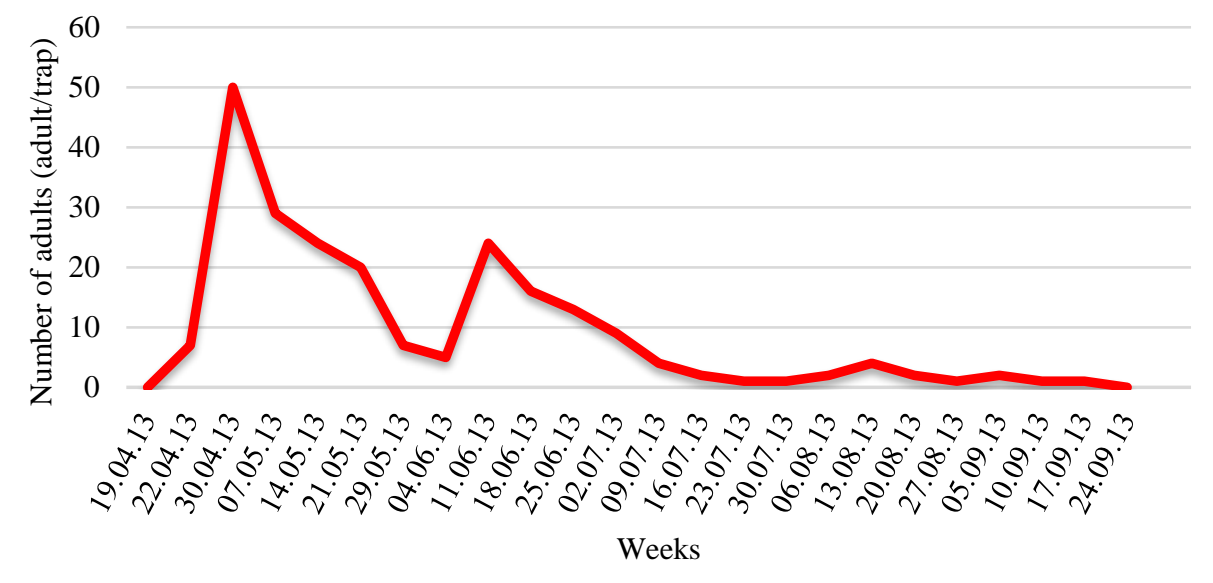

Figure 1- Flight activity of European grapevine moth in Ankara, Kalecik district in 2013 


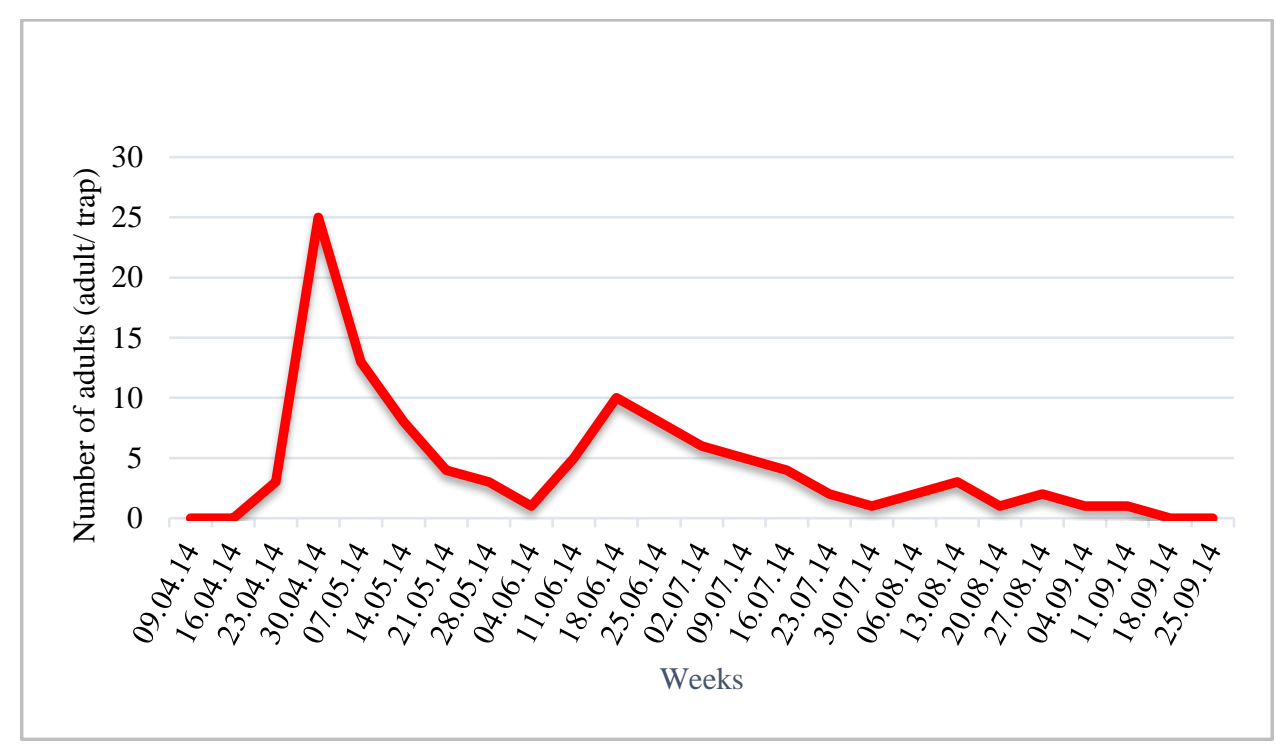

Figure 2- Flight activity of European grapevine moth in Ankara, Kalecik district in 2014

The first adult was obtained in the third week of April in both years. The date when the first adults of European grapevine moth were seen in vineyards was different in studies conducted in different provinces and regions.

In this context, Güçlü and Ünlü (2018) obtained the first adults in different districts of Manisa in late March, Mamay \& Çakır (2014) in Şanlıurfa on May 19, Öztürk \& Acı̈̈z (2010) in Mersin, Tarsus district in late February-early March. Regional climate, ecological differences and plant phenology are considered to have affected the time when the first adult was seen.

Pentad temperature and relative humidity values were $13.8^{\circ} \mathrm{C}$ and $48 \%$ (Figure 3 ) when the first adult was seen in 2013 , while it was $17.1^{\circ} \mathrm{C}$ and $47 \%$ in 2014 (Figure 4). It was recorded that pentad temperature values were $13.8-17.1^{\circ} \mathrm{C}$ and relative humidity values were $47-48 \%$ when $L$. botrana adults were seen in these years. In a study performed in Tarsus district, Öztürk $\&$ Aciöz (2010) stated that the pentad temperature and relative humidity values were $14.1-13.5{ }^{\circ} \mathrm{C}$ and $66.5-70.3 \%$ respectively when L. botrana adults were first caught. Kovanc1 et al. (2005) stated that the pentad temperature values were $13.3-15.3{ }^{\circ} \mathrm{C}$ and relative humidity values were 67.0-71.0 when L. botrana adults were first caught in İznik vineyards. Figure 1 shows that the highest number of adults caught in traps in 2013 was on April 30, with 50 adults/trap/week and on June 11, with 24 adults/trap/week whereas the highest number of adults caught in traps in 2014 was on April 30, with 25 adults /trap/week and on June 18, with 10 adults /trap/week (Figure 2). At the first peak of the population, pentad air temperature and relative humidity were $19.5^{\circ} \mathrm{C}$ and $44 \%$ in 2013 , and $16.4{ }^{\circ} \mathrm{C}$ and $61 \%$ in 2014 . At the second peak point of the population, pentad air temperature and relative humidity were $19.1^{\circ} \mathrm{C}$ and $52 \%$ in 2013 , and $21.4^{\circ} \mathrm{C}$ and $58 \%$ in 2014 . It was concluded that European grapevine adults had two peaks during the year, April 30 and June 11 in 2013 and April 30 and June 18in 2014. However, in both years, during the near-harvest period, there was an increase in the number of adults with 4 adults/traps/week in 2013 and 3 adults /trap/week in 2014 on August 13; which pointed out that there may be a third generation. In their study conducted in Ankara, Şereflikoçhisar district, Ataç et al. (1987) stated that the third generation of L. botrana had two small flights towards the end of August; however, there were not any eggs and larvae in cluster controls. It was observed that L. botrana generally produced 3-4 generations in Çanakkale and Şanlıurfa (Özpınar et al. 2004; Mamay \& Çakır 2014), and 4 generations in Bursa, Tarsus, and Manisa (Kovanc1 et al. 2005; Öztürk \& Acı̈̈z 2010; Güleç \& Ünlü 2018). In European vineyards, L. botrana is active from early spring to late summer (Noma et al. 2010). Abiotic factors may have a major effect on the population dynamics of $L$. botrana at all insect stages. In particular, temperature acting on adult and larval stages regulates female fecundity (Torres-Vila 1996). Adult activity, i.e. flight, feeding, calling, mating and egg-laying, is principally displayed at twilight, although some activity can also occur at daybreak or at any time on cloudy days. Water availability is necessary for adults to reach their potential reproductive capacity (Torres-Vila et al. 1996). The twilight temperature must be above $15-16^{\circ} \mathrm{C}$ for two consecutive days and this condition must continue in the next days for the first generation adults of L. botrana to mate and lay eggs (Anonymous 2011). While it could be understood that the duration of European grapevine moths in nature varies according to the different ecology, it is thought that this may be due to climate conditions and ecological differences. 


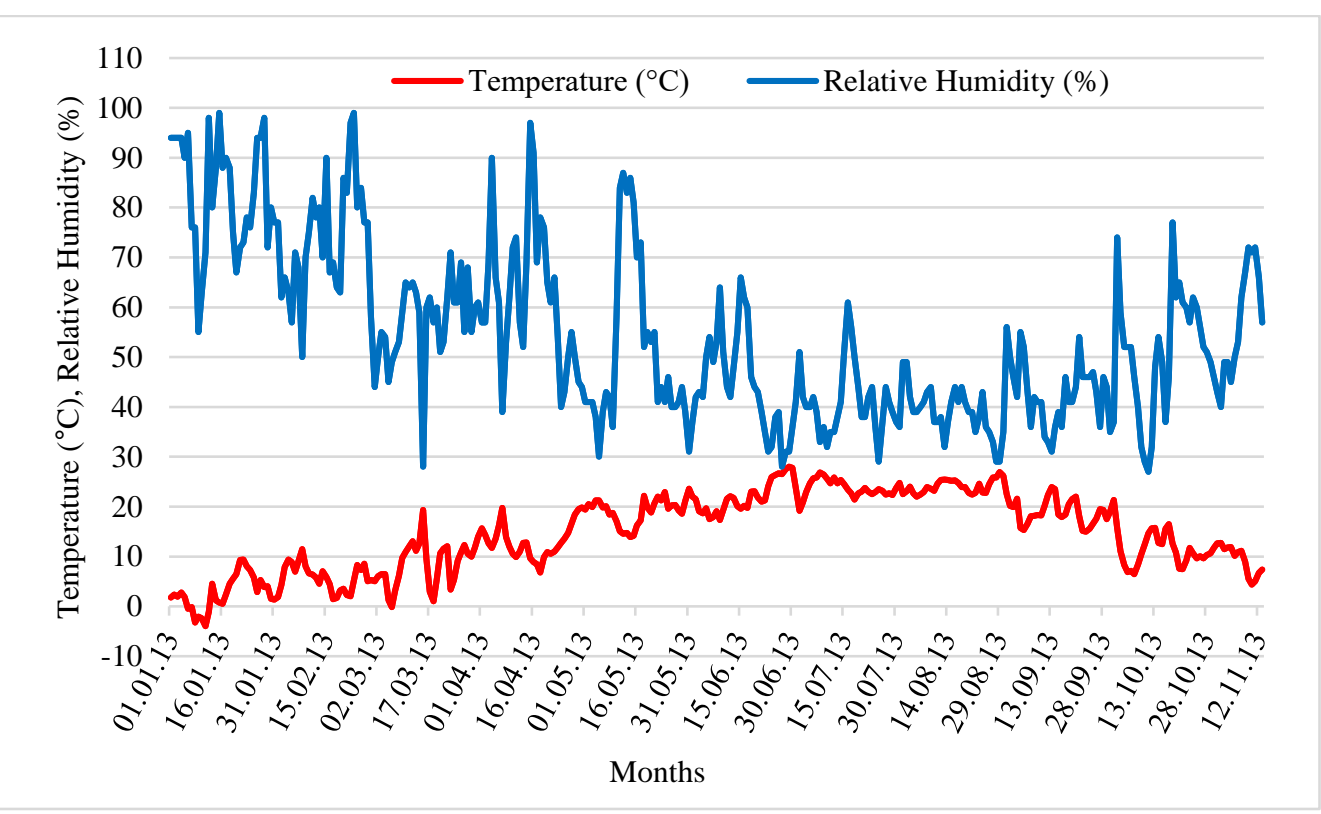

Figure 3- Temperature and relative humidity values in Ankara, Kalecik District in 2013 (January-November)

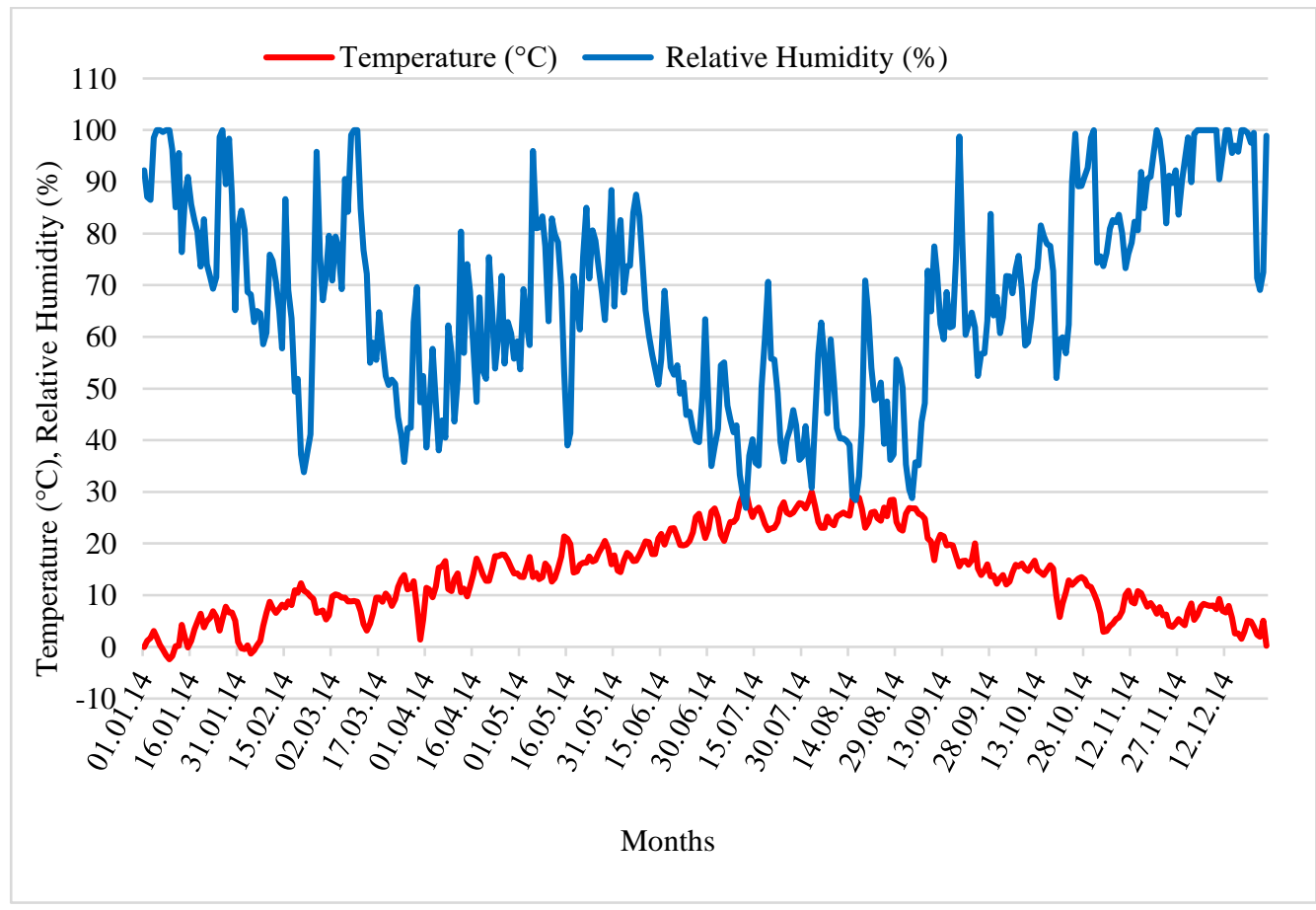

Figure 4- Temperature and relative humidity values in Ankara, Kalecik District in 2014 (January-December)

It was concluded that the dates when the first adult was caught in sex pheromone traps in both years coincided with the dates when leaves were observed phenologically in grapevines. It was also deduced that the adult population phenologically had its first peak during the budding period of clusters in grapevines and its second peak during the unripe grape period. In studies carried out in different regions, the adult population of the European grapevine moth was reported to have its first peak during the flowering period its second peak during unripe grape or the beginning of the ripe period (Mamay \& Çakır 2014; Öztürk \& Aciöz 2010).

The optimum laying temperature of L. botrana is $20-25^{\circ} \mathrm{C}$, and the twilight temperature must be above and $15-16^{\circ} \mathrm{C}$ for two consecutive days and continue in this manner in the following days for adults in the first generation to mate and lay eggs (Anonymous 2008). The twilight temperature was over $15-16{ }^{\circ} \mathrm{C}$ in 2013, on April 26 and 27. It was reported that during the dates when European grapevine moth adults were obtained and suitable twilight temperatures were observed, temperatures were usually below $20{ }^{\circ} \mathrm{C}$ and this continued until the third week of May and went above $20{ }^{\circ} \mathrm{C}$ for the next few days; however, temperatures were once again below $20{ }^{\circ} \mathrm{C}$ in the first week of June (Figure 3). In 2014, it was observed that the average temperatures were generally below $20^{\circ} \mathrm{C}$ since the date when European grapevine moth adults were seen and that temperatures 
were around $20{ }^{\circ} \mathrm{C}$ only for a few days in the second week of May. Low temperatures continued until the second week of June, then started to rise above $20^{\circ} \mathrm{C}$, and it was observed that the twilight temperature was above $15-16^{\circ} \mathrm{C}$ on May $15-16$; however, this did not continue in the following days (Figure 4). In the study performed on the population dynamics of L. botrana, Briere \& Pracros (1997) reported that the temperature must be between $8-32^{\circ} \mathrm{C}$ to provide the egg and larvae development of the pest. Starting from the days when the twilight temperatures were suitable for spawning of European grapevine moth in both years, pest eggs were searched in each lot, 150 clusters apiece; however, no eggs were found. Generally, it is thought that changes in temperature below $20{ }^{\circ} \mathrm{C}$ and unstable temperature changes affect the laying of $L$. botrana. The total of effective temperatures in Kalecik, starting from January 1, 2013, reached $118.67 \mathrm{~d} / \mathrm{d}$ on May 6, $126.74 \mathrm{~d} / \mathrm{d}$ on May 7, whereas the total of effective temperatures was close to $120 \mathrm{~d} / \mathrm{d}$ on May $14(119.2 \mathrm{~d} / \mathrm{d})$ and was $128.6 \mathrm{~d} / \mathrm{d}$ on May 15 . If the total of effective temperatures approach or reach $120(\mathrm{~d} / \mathrm{d})$ as of January 1, it means that the first larvae have emerged and the cluster phenology was undergoing the budding period at that time. In addition to catching adults in traps on these dates, due to the suitability of a total of effective temperatures and cluster in phenological manner, European grapevine moth larvae were searched in each lot, 150 clusters apiece. However, larvae and larvae damage was not found in these clusters. Adults in the second generation of L. botrana reached the peak on June 11, 2013. The total of effective temperatures was found to be $520.86 \mathrm{~d} / \mathrm{d}$ on June 11 . It is reported that the most suitable flight temperature for adults is $20-27{ }^{\circ} \mathrm{C}$ with relative humidity of $40-70 \%$ (Anonymous 2011). Although the average temperature in June in Kalecik district was $21.2^{\circ} \mathrm{C}$ and it was rainy between June $12-18$, the average relative humidity was $43 \%$. Adults in the second generation of $L$. botrana reached the peak on June 18, 2014. Starting from January 1, the total effective temperatures reached $517.5 \mathrm{~d} / \mathrm{d}$ and the number of adults caught in traps rapidly decreased while the presence of eggs, larvae, and damage caused by larvae in the second generation could not be found as of July 5 . Therefore, there was no spraying against the second generation. During this period, L. botrana eggs and larvae were searched in each lot, 150 clusters apiece; however, no eggs or larvae could be found. When this is evaluated together with climate data, temperature and relative humidity, values seemed close to the minimum value for adult flight, and this may affect adult flight, therefore, spawning. Harvesting in the trial vineyard in Kalecik was performed in the last week of August in both years. Cluster samples were collected to identify damaged ones during harvest, and no European grapevine moth egg or larva was found. Even though there were L. botrana adults in Kalecik both in 2013 and 2014, the reason why no egg or larvae or related damage were observed may be that unstable climate conditions can be effective as it is stated above. Moreover, it was concluded that these values were close to minimum value for adult flight; therefore, it may affect female butterflies to lay eggs. Coscollá \& Dávila-Zurita (1983) concluded that there was a clear correlation between climate and the L. botrana's biology and that the main determinant of the pest's population fluctuations was climatic factors, by using ecoclimatograms.

It was reported that abiotic factors could have a major effect on population dynamics of L. botrana's at all biological stages, and in particular, that the effective temperature regulated fertility during the adult and larva stage (Torres-Vila 1996), adult activity and longevity (Bovey 1966), and egg deaths (Coscollá \& Dávila-Zurita 1983). Although in literature it has been discussed that the ecological conditions in the study area may affect the L. botrana's egg laying and damage status, ecological conditions alone are not considered to have an effect on its egg laying and damage status. It has been determined that the damage status of L. botrana is different from Kalecik karası in some grape varieties grown under the same ecological conditions.

Around the vineyard, where the trial was conducted, there were 2-3 decares of grape varieties such as Yalova pearl and Black muscat (Muscat Hamburg). During the years when the study was conducted, it was observed that these grape varieties were infested with European grapevine moths, though at a low density. Falling of buds were seen in clusters due to the damage caused by the first generation larva. Also, damage in grapes was seen by the second generation. In addition to adult flight, considering the overall temperatures and phenological features of the grapevine, it was observed that there were egg and larvae phases of European grapevine moth in these grape varieties and that there was damage during the budding and unripe grape period. It could be deduced that adults caught in traps established in vineyards of Kalecik karas1 variety flew to vineyard areas of Yalova pearl and Black muscat varieties and they formed populations there.

Even though adult flight activity of European grapevine moth was detected in vineyard areas of Kalecik karas1 grape variety, as it was mentioned before about this variety, there were no eggs or larvae damage. In a study performed on the preference of grape varieties of L. botrana, it was reported that the females had several effects on the host selection in four grape varieties (Sharon et al. 2009). Similarly, Birgücü et al. (2015), demonstrated that L. botrana was observed the most in Yalova pearl and the least in Alevsiz variety, among grape varieties of Yalova Pearl, Alevsiz Sultana, and Red Seedless. In another study, researchers found that $L$. botrana's 1st generation caused the highest damage to Barış grapes, 2nd generation to the Yalova İncisi-Trakya İlkeren, and 3rd generation to the Hönüsü-Italia grape varieties (Aslan \& Candan 2018). Although the preference was not investigated in our study, there is are indications that there might be a variety of preference. As it is supported by findings in Yalova pearl and Black muscat harvested around vineyard areas close to Kalecik karasi grape variety were damaged by $L$. botrana and that Kalecik karası was not. Studies were done in different oviposition stimulants or deterrents of L. botrana on different grape varieties. The mated females of L. botrana typically oviposit at twilight and lay a series of single eggs, responding to olfactory cues (Gabel \&Thiéry 1994; Hurtrel \& Thiéry 1999; Masante-Roca et al. 2002) and taste stimuli (Maher \& Thiéry 2004; Maher et al. 2006). The contact-chemoreceptors from both the tarsae and ovipositor were determined to respond to different oviposition stimulants or deterrents (Maher \& Thiéry 2004; Maher et al. 2006). In oviposition choice assays, nonvolatile polar compounds extracted from ripe grape berries of different grapevine varieties stimulate the oviposition of the $L$. botrana female (Maher \& Thiéry 2004), whereas fatty acids and their derivatives were shown to be deterrent (Gabel \& Thiéry 
1996). In a study carried out in our country, it was identified that there is a total of 5 organic acids (citric, tartaric, malic, succinic and fumaric acids) and 14 anthocyanins ( 5 monoglycosides, 5 acetyls and 4 coumaryls) in Kalecik karası. In addition, a total of 8 phenol compounds (gallic acid, protocathic acid, catechin, epicatechin, B1, B2, B3 and B4 dimers) were detected in the seeds of Kalecik karası berries (Kelebek 2009). Kalecik karası grape berries have a deep purple, almost blue color, thick skins, medium size and frequent cluster. Snjezana (2004) stated that damage of L. botrana to cultivars can be said to be attributable to cluster compactness, epidermis thickness and sugar content of grapes.

So far, no study has been conducted on the relationship between the morphological and histochemical features of this variety with L. botrana. The results of the present study showed that $L$. botrana does not prefer the Kalecik karas 1 grape variety, but detailed studies suggested that this variety is resistant to L. botrana. In conclusion, when both years are evaluated the study conducted on the damage status of European grapevine moth on Kalecik karas1 grape variety harvested in vineyard areas in Kalecik district for two consecutive years, revealed that even though there were European grapevine moth adults, no eggs, larvae, and therefore, no damage was present. When all the data of the study are evaluated together, it has been concluded that there is no need for a chemical control against European grapevine moth in vineyard areas where Kalecik karası grape variety is produced.

\section{Conclusions}

The results of this study clearly demonstrate that it is not necessary to use of chemicals to control L. botrana in the vineyards of Kalecik karas1. Generally, when adults are caught using traps for European grapevine moth with a suitable total of effective temperatures and in phenological features, Provincial Directorate issues a warning on the matter and growers make the disinfestation. In vineyards of Kalecik karas1, it can be advised to farmers not to apply chemical control against L. botrana through the provincial directorate's technical staff. Since Kalecik karas1 grape variety not only occupies an important place in wine-making in our country but also is consumed as a table grape variety, demonstrating that there is no need for spraying application under integrated pest management against L. botrana will contribute to risk-free agriculture for human health and environment without any insecticide residue. In future studies, conduction of experiments to reveal the resistance of Kalecik karas1 against $L$. botrana under controlled and semi-field conditions is recommended. In addition, considering the changing of climatic conditions and the presence of different grape varieties grown in our country, the investigation of the damage status of L. botrana on different grape varieties is suggested.

\section{Acknowledgements}

This study was supported by the Ministry of Agriculture and Forestry, General Directorate of Agricultural Research and Policy, Project No: TAGEM-BS-11/04-01/03-01.

\section{References}

Altındişli F Ö (2014). European grapevine moth and its control in vineyards. Journal of Turkey Seed Growers Association 3(11): $42-44$

Altındişli F Ö \& Kısmalı Ş (1996). Researches on the using possibilities of mass - trapping technique against Lobesia botrana Den. Schiff (Lepidoptera: Tortricidae) in the Agean Region. 3rd Turkish National Congress of Entomology, September 24-28 1996, Ankara, 91 p.

Anonymous (2008). European grapevine moth, Lobesia botrana Den.et Schiff. (Lepidoptera: Tortricidae) Plant Protection Technical Instruction, GDAR, Volume 4, pp: 334-343 (In Turkish)

Anonymous (2011). European grapevine moth, Lobesia botrana Den.et Schiff. (Lepidoptera: Tortricidae) Vineyard IPM Technical Instruction, GDAR pp: 15-27 (In Turkish)

Ataç Ö, Çevik T \& Zeki C (1987). Investigations on the determination of chemical application time by using sex-pheremon traps against European Grape berrymoth Lobesia botrana Den. et Schiff. (Lep., Tortricidae) and the possibilities of the use of these traps in Agricultural warning and forecasting program. Proceedings 1st Turkish National Congress of Entomology, October 13-16 1987. No: 3 pp: 119-128

Aslan M M, \& Candan G (2018). Determining the damage level of the European grapevine moth Lobesia botrana (Denis et Schiffermüller) in different grape varieties. KSU Journal of Agriculture and Nature 21(4): 482-488. DOI:10.18016/ksudobil.349828

Birgücü AK, Turanlı F, Gümüş E, Güzel B \& Karsavuran Y (2015). The effect of grape cultivars on oviposition preference and larval survival of Lobesia botrana Den. \& Schiff. (Lepidoptera: Tortricidae). Fresenius Environmental Bulletin 24 (1): 33-38

Bovey P (1966). Superfamille des Tortricoidea. In: Balachowsky AS, ed. Entomologie Appliquée à l'Agriculture Vol. 2 (1). Paris, France: Masson et Cie. pp: 859-887

Briere J F \& Pracros P (1997). Modelisation de la dynamique des populations de i’eudemis de la vigne (Lobesia botrana Den.\&Schiff.). Le Corum, Montpellier, France.Tome 2. Paris, France; ANPP pp: 373-380 (https://hal.inrae.fr/hal-02771667)

Caffarra A, Rinaldi M, Eccel E, Rossi V \& Pertot I (2012). Modelling the impact of climate change on the interaction between grapevine and its pests and pathogens: European grapevine moth and powdery mildew. Agriculture, Ecosystems \& Environment 148: 89-101. DOI: 10.1016/j.agee.2011.11.017

Coscollá R \& Dávila-Zurita M (1983). Influence of climatic factors on the severity of attack by Lobesia botrana in vineyards in the Valencia region. OEPP/EPPO Bulletin 13(2): 97-102

Davydov G N (1976). The phenology of the grape moth. Zashchita Rastenii 2: 52

Gabel B \& Thiéry D (1994). Non-host plant odour (Tanacetum vulgare; Asteraceae) affects the reproductive behaviour of Lobesia botrana (Lepidoptera: Tortricidae). Journal of Insect Behaviour 7: 149-157. DOI: 10.1007/BF01990077

Gabel B \& Thiéry D (1996). Oviposition response of Lobesia botrana females to long-chain free fatty acids and esters from its eggs. Journal of Chemical Ecology 22: 161-171. DOI: 10.1007/BF02040207 
Gilioli G, Pasquali S \& Marchesini E (2016). A modelling framework for pest population dynamics and management: An application to the grape berry moth. Ecological modelling 320: 348-357. DOI: 10.1016/j.ecolmodel.2015.10.018

Güleç F \& Ünlü L (2018). Determination of population development and infestation ratio of Lobesia botrana Den. \& Schiff. (Lep.: Tortricidae) in Ahmetli and Turgutlu (Manisa) districts. Anadolu Journal of Agricultural Sciences 33: 191-201. DOI: 10.7161/omuanajas.391372

Hurtrel B \& Thiéry D (1999). Modulation of flight activity in Lobesia botrana Den \& Schiff (Lepidoptera: Tortricidae) females studied in wind tunnel. Journal of Insect Behaviour 12: 199-211. DOI: 10.1023/A:1020914800170

Karataş H, Değirmenci D \& Ağaoğlu Y S (2010). The effects of fruiting cane direction on grape yield and quality of Kalecik Karası grape cultivar (Vitis vinifera L.). Journal of Agricultural Faculty of Uludag University 24 (1):37-46. (https://dergipark.org.tr/tr/download/articlefile/154102)

Kelebek H (2009). Researches on the phenolic compounds profile of öküzgözü, bogazkere and kalecik karasi cultivars grown in different regions and their wines. Çukurova University, Institute of Science, PhD Thesis (unpublished), Adana-Turkey $255 \mathrm{pp}$.

Kovancı B, Türkmen C \& Kumral N A (2005). Investigations on the adult population fluctuation of the harmful European grapevine moth [Lobesia botrana Den. \& Schiff. (Lep.: Tortricidae)] in the vineyards in Iznik (Bursa) district. 6th Turkey Viticulture Symposium, September 19-23 2005, Tekirdağ-Turkey 1: 289-296

Maher N \& Thiéry D (2004). A bioassay to evaluate the activity of chemical stimuli from grape berries on the oviposition of Lobesia botrana (Lepidoptera: Tortricidae). Bulletin of Entomological Research 94(1): 27-33. DOI: 10.1079/BER2003276

Maher N, Thiéry D \& Stadler E (2006). Oviposition by Lobesia botrana is stimulated by sugars detected by contact chemoreceptors. Physiological Entomology 31: 14-22. DOI: 10.1111/j.1365-3032.2005. 00476.x

Mamay M \& Çakır A (2014). Determination of adult population fluctuation and infestation rate of European grapevine moth [Lobesia botrana Denis \& Schiffermüller (Lepidoptera: Tortricidae)] in the vineyards in Şanlıurfa Central county. Plant Protection Bulletin (Bitki Koruma Bülteni) 54(2): 103-114 (https://dergipark.org.tr/tr/download/article-file/428373)

Martin-Vertedor D, Ferrero-Garcia J J \& Torres-Vila L M (2010). Global warming affects phenology and voltinism of Lobesia botrana in Spain. Agricultural and Forest Entomology 12: 169-176. DOI: 10.1111/j.1461-9563.2009. 00465.x

Masante-Roca I, Gadenne C \& Anton S (2002). Plant odour processing in the antennal lobe of male and female grapevine moths, Lobesia botrana (Lepidoptera: Tortricidae). Journal of Insect Physiology 48: 1111-1121. DOI: 10.1016/s0022-1910(02)00204-4

Noma M, Colunga-Garcia M, Brewer J, Landis A \& Gooch P (2010). European grapevine moth Lobesia botrana. Michigan State University's invasive M. species factsheets pp.1-2. (https://www.canr.msu.edu/ipm/uploads/files/Forecasting_invasion_risks/ european GrapevineMoth.pdf)

Önçağ G (1975). Studies on identification, distribution, biology, damage, natural enemies and chemical control possibilities of the European grapevine moth in the Aegean Region. İzmir Directorate of Agricultural Quarantine. Technical Bulletin No: 26, 68 p.

Özpınar A, Albayrak A \& Görür S E (2004). Determination of population development of European grapevine moth [Lobesia botrana Den. \& Schiff. (Lepidoptera: Tortricidae)] and the number of generation in the vineyard areas of Çanakkale province. Proceedings 1st Turkish National Congress of Plant Protection, September 08-10 2004, Samsun-Turkey pp.101

Öztürk N \& Acıöz S 2010. The adult population dynamics of the European grapevine moth [Lobesia botrana Den.\&Schiff. (Lepidoptera: Tortricidae)] in the vineyards in Tarsus (Mersin-Turkey). Plant Protection Bulletin (Bitki Koruma Bülteni) 50(3): 111-120 (https://dergipark.org.tr/tr/download/article-file/41596)

Pavan F, Floreani C, Barro P, Zandigiacomo P \& Dalla Montà L (2013). Occurrence of two different development patterns in Lobesia botrana (Lepidoptera: Tortricidae) larvae during the second generation. Agricultural and Forest Entomology 14: 398-406. DOI:10.1111/afe.12027

Sharon R, Zahavi T Soroker V \& Harari A (2009). The effect of grape vine cultivars on Lobesia botrana (Lepidoptera: Tortricidae) population levels. Journal of Pest Science 82(2): 187-193. DOI: 10.1007/s10340-008-0238-5

Snjezana H (2004). Susceptibility of Some Grapevine Cultivars in Area of Vineyards of Podgorica on the Attack of European Grape Berry Moth- Lobesia botrana Den. \& Schiff. (Lepidoptera: Tortricidae). Acta Horticulture 652: 355-358 DOI: 10.17660/ActaHortic.2004.652.46

Torres-Vila L M (1996). Efecto de la temperatura de desarrollo preimaginal sobre el potencial biótico de la polilla del racimo de la vid, Lobesia botrana (Denis y Schiffermuller, (1775)) (Lepidoptera: Torticidae). SHILAP Revista de Lepidopterologia 24:197-206

Torres-Vila L M, Stockel J \& Rodriguez-Molina M C (1996). Efecto de la indisponibilidad de agua sobre el potencial biótico de la polilla del racimo Lobesia botrana Den. y. Schiff. (Lepidoptera: Tortricidae). Boletn de Sanidad Vegetal, Plagas 22:443-449 (https://www.mapa.gob.es/ministerio/pags/biblioteca/revistas/pdf_plagas/BSVP-22-02-443-449.pdf)

TUIK (2019). Crop Production Statistics, Grape, Retrieved in June 82020 from (http://www.tuik.gov.tr/PreTablo.do?alt_id=1001)

(C) 2022 by the author(s). Published by Ankara University, Faculty of Agriculture, Ankara, Turkey. This is an Open Access article distributed under the terms and conditions of the Creative Commons Attribution (CC BY) license (http://creativecommons.org/licenses/by/4.0/), which permits unrestricted use, distribution, and reproduction in any medium, provided the original work is properly cited. 